\title{
DAO PHILOSOPHY AND NON-ACTION MANAGEMENT
}

\author{
Dilin Yao \\ Shanghai Maritime University, P.R.China \\ Jun Chen \\ Shanghai University, P.R.China
}

\begin{abstract}
Traditional Chinese philosophy can serve as a rich source of insight for management studies. The aim of this article is to discuss two main aspects of Dao philosophy, non-action management and non-action leadership. The article makes two contributions to knowledge. First, it outlines a conceptual model of non-action management based on Dao De Jing. Second, it provides a conceptual model of non-action leadership based on Laozi's three essentials to supplement the non-action management model. It is argued that the non-action management and non-action leadership model offers new opportunities for management research and practice, as well as contributing to existing leadership theories. The article concludes with a discussion of the practical value of considering Dao philosophy as an underlying approach to management.
\end{abstract}

Keywords: Dao Philosophy; Non-action; Management; Leadership

JEL code: M190

\section{Introduction}

The prosperity during the reign of Wen and Jing emperors of the Han dynasty and excellent governance during the Zhenguan Times attributed to the emperors' learning and practicing the non-action management ideas in Dao De Jing. Non-action management in nature is to respect and love human being. This can be explained in Chapter 7 of Dao De Jing that heaven and earth have been in existence eternally, because they do not exist for themselves. Their existence is for the nourishment of all myriad of things, by regarding others' affairs ahead of their own and placing others ahead of themselves. Dao accomplishes greatness by not having a selfish heart. Management achieved success by not having a selfish heart either. Laozi wrote Dao De Jing to guide hereditary rulers (Ma and Tsui, 2015). The ancient philosophy has implications for contemporary management theory and practice (Chapter 14). Thus, this article rooted in Dao philosophy arising from the book of Dao De Jing.

Dao De Jing consists of two parts: Dao Jing and De Jing with five thousand words. Laozi as the author of this book identified Dao as the essence of the universe and the nature of all things in the earth. In the modern society, we could gain wisdom from Dao in the attempt to pursue the root cause of all tangible phenomena in life, including the scientific theories and practices. 
Dao through the main principles of naturalism, Yin Yang and harmony offers instructions and guidelines for leadership and management (Barkema et al., 2015). Dao philosophy is presented in this research as a philosophical and wise pattern of management and leadership. The purpose of this article is to elaborate on constructing the non-action management and leadership model based on Dao philosophy, drawing on the essential management-related content from the 81 chapters of the Dao De Jing. This paper's discussions of the relevant chapters (which have been translated by the author) rely on mainstream interpretations of the Dao De Jing (Yao and Gan, 2013).

The specific notion illustrated in this paper is non-action management and leadership with the purpose to make essential contributions to knowledge: First, it outlines a conceptual model of non-action management. Second, it provides a conceptual model of non-action leadership based on Laozi's three essentials to supplement the non-action management model. This paper has three sections. First, Dao philosophy and human nature are introduced. Then, a non-action management model based on Dao philosophy is constructed, consisting of six elements. Third, a non-action leadership model is constructed based on Laozi's three essentials to supplement the non-action management model. Finally, the paper concludes with a discussion of the value of considering Dao philosophy in relation to management and leadership.

\section{Dao Philosophy and Human Nature}

Dao is mysterious and difficult to be explained explicitly (Ma and Tsui, 2015). In the first Chapter, Laozi illustrated Dao as the foundation to build up the whole ideas of his book. Dao represents the truth that pre-existed before myriad of things in the universe were created. It also represents the energy of the void that permeates the tangible and intangible world. Therefore, it is very difficult for human beings to use words to describe Dao. The profundity of the essence of Dao is imageless, soundless and formless represent (Chapter 14 and 21). Dao permeates heaven and earth in the cosmos unceasingly.

As Dao is the universal law (Jing and Van de Ven, 2014), people should follow the principle of Dao (Ma and Tsui, 2015; Lee et al., 2008). Since eons ago, the saints upheld the essence of Dao to govern the world. The path of the great Dao is smooth and wide (Chapter 53). However, people pay more attention to the tangible things. It is because of the prolonged negative influence people have received from the external environment (Chapter 70). Dao philosophy should be reconsider guiding today's management. Dao is most tranquil and it embraces nonaction (Chapter 39).

Chapter 37 presented that Dao adheres to non-action. Due to its attribute of non-action, Dao accomplishes everything. Everything in this world, including the changes of the five elements (metal, wood, water, fire and earth) and the coordination of the four seasons are manifestations of Dao. Dao accomplishes everything by adhering to non-action. Everything in the world follows the course of nature and progresses along the stages of development, maturity, old age and ultimately death (Chapter 30). Everything has their own timing to grow and mature with Dao non-action principle (Chapter 51). The non-action of Dao has enabled all myriad of things 
to grow and develop concurrently without contradiction (Chapter 43).

Chapter 52 presented that the origin of everything in the world is Dao. For men, Dao is our original nature. Thus, human being as one of the four greats of the universe (Chapter 25) has the Dao non-action nature. The leader is based on the subordinate (Chapter 36 and 39). Thus, leaders should know and follow the non-action nature of subordinates. Chapter 11 presented that to make a container, an empty space has to be created to hold an object. Tangible objects are created to provide for people's convenience. Intangible space is needed for people's activities. So "Wu" (non-) is the real function and principle. Based on "Wu", active behaviors should be conducted which is "Wei" (action-). This is "Wu Wei" (non-action) which doesn't mean to do nothing, but doing on the basis of Dao principle, doing "the right thing at the right time" (Javary, 1997, p. 9). Non-action management is based on the cultivation of non-action leadership. The following sections would construct the non-action management and non-action leadership model based on Dao philosophy.

\section{Constructing a Non-action Management Model}

Based on the non-action nature of human being, non-action management is necessary. Chapter 17 presented that a successful emperor allows his subjects to handle their livelihood in accordance with nature. Enlightened rulers of the ancient times taught their people without saying many words and handled the country's affairs without any acknowledgement. Naturally, people in the country followed their emperors' directions. This kind of emperor can be regarded as achieving the highest level of governing a country with non-action management. The deepest profundity lies in the midst of non-action (Chapter 48). As Chapter 60 presented that to govern a large country is like frying many little fish. One should not stir too often or the little fish will crumble. A spirit of harmony and auspiciousness can be achieved if the leaders in power uphold Dao's attribute of non-action, integrity and sincerity. Based on Dao De Jing, elements to construct non-action management will be stated as follows (Figure 1):

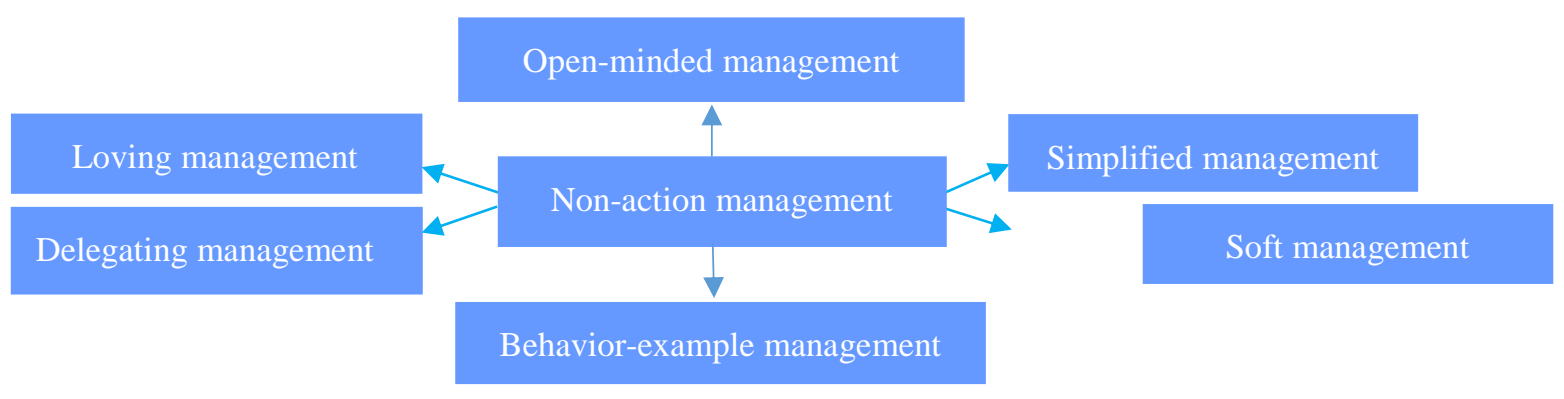

Figure 1. Non-action Management Construction Model

\section{Simplified management}

Chapter 32 presented that the term "simplicity" describes the appearance of Dao. If emperors and high officials are able to uphold this "simplicity", which is inherent in their original nature, they can govern the country with non-action. Everyone will be obedient to the rulers and live happily in peace and prosperity. Benevolent emperor who governs the country in this most 
natural way. Chapter 65 presented that in the past, a ruler who governed with the great Dao never taught his people to be conniving. Instead, he taught his people to be pure and honest. There was no need for a superior person whose ability surpasses that of tens or hundreds of people, and people would live in peace and harmony (Chapter 80). However, Chapter 18 presented that as technology became more advanced and civilization more developed, human hearts became more conniving and hypocritical. People no longer upheld benevolence, righteousness and morality. Therefore, there were endless incidents of trickery and scams. Thus, Chapter 3 indicated that in governing the world, the saints teach people to first sever all evil intentions and devious thoughts, to eliminate pride, conceit, and competitive nature to employ unscrupulous means to succeed. Eventually, people can maintain their purity, peace and harmony, without conceit and the desire to fight. Accordingly, if everyone focuses on the nonaction aspect of our original nature in governing the world, how can the world not be governed well?

\section{Open-minded management}

Chapter 2 presented that "have" and "have not", "difficulty" and "easiness", "long" and "short", "high" and "low", "soft voice" and "loud voice", "front" and "back" are all relative. After the saints realized this phenomenon of relativity, they were able to uphold their original nature and handle their affairs with the perspective of "non-action" (letting things take their own course) in order to transcend from the burden of praises and afflictions. Calamities and good fortune are also relative and interchange between each other. As Chapter 58 indicated that the eventual arrival of good fortune is found in the midst of calamities. For instance, a person is only able to appreciate the preciousness of good fortune after he encounters calamities. Afterwards, he will understand the importance of accumulating merits and virtues. He will seek the way to achieve eternal happiness. Conversely, the eventual arrival of calamities is also found in the midst of good fortune. For instance, a person is not able to appreciate the preciousness of good fortune if he has never encountered calamities. He will engage in devious acts, lead a life of extravagance and be wasteful. Thus, such a person will have created numerous sins. When the conditions ripen, calamities will arrive. This principle can also be applied into the management practice. Open-minded management is objective in this relative world.

\section{Loving management}

The great saints in the past, such as Emperor Yao, Shun and Yu, provided perfect examples of loving management. Chapter 73 indicated that it seems that Dao has already determined that karmic retributions will occur. Nothing can escape from the net of karmic retribution. Loving management will benefit in the net of karmic retribution. Unlike people always engage in superfluous things and are prone to flatter those in superior positions in a hypocritical manner, Chapter 77 presented that Dao will use whatever is in surplus to compensate what is lacking. Dao balances all things. As Chapter 49 presented that a saint does not have a heart of discrimination. Even when a saint encounters unkind people or inglorious events, he will still try to inspire them with his virtue of benevolence, to convert an untrustworthy person to be trustworthy. A saint's heart is united with everything, he does not possess the intention to 
destroy or forsake any plants and animals (Chapter 27), and is willing to forgive a person who is truly repentant (Chapter 62). Only governing with morality, benevolence and righteousness is able to successfully rule the world (Chapter 48).

Emperor Qin Shi Huang used his powerful army to strengthen his hegemony. His kingdom was quickly doomed because he acted against nature and people did not support him. People who are fond of killing and fighting are the main reason calamities take place (Chapter 69). To be in accordance with karmic retribution, one must minimize arguments with others (Chapter 23). Strong wind and torrential rain will not last forever. Great calamities will soon befall those who behave deviously without any fear (Chapter 72). Chapter 31 presented that efficient killing weapons are never auspicious. Even the animals and plants despise them. Weapons are only used when it is absolutely necessary. Chapter 74 and Chapter 75 indicated that people suffer greatly under a tyrannical ruler who suppresses his people. When people are unable to live in peace and are no longer afraid to die, they will resist by staging a revolution. Under these circumstances, it will be useless for the ruler to intimidate his people with execution. Thus, in the management, strict punishment should be avoided used.

\section{Delegating management}

Chapter 68 presented that an official who is most efficient in delegation always cares for his subordinates. Since this official is considerate of his subordinates and cares for them sincerely, he is completely accepted and supported by his subordinates. This demonstrates the real power in delegation. The non-action management gives authority and freedom. A ruler should never impose excessive, harsh rules and regulations if he intends to provide convenience to the people, and this is the only way to bring about prosperity (Chapter 57).

\section{Behavior-example management}

Chapter 43 presented that the saints, who constantly uphold their true nature, always set an example for others and practice what they preach. This wordless teaching is better than teachings with words. Nothing in this world can compare to this wordless teaching. Chapter 5 indicated that nowadays, peoples' state of mind is either too far left or too far right. They are unable to uphold the principle of the Doctrine of the Mean. It is better to maintain the principle of upholding the center with less words and more exemplary behavior. Then, according to the social learning theory, the behavior-example management will impact extensively. As Chapter 54 indicated that if a virtuous person successfully regulates his family, everyone in the family benefits from his virtue. If a virtuous person is able to reform his community, everyone in the community benefits from his behavioral teachings. If virtue is used to reform the country, the country will be prosperous. If virtue is used to reform the whole world, everyone will be inspired.

\section{Soft management}

Chapter 76 presented that when a person is alive, his body is soft. Only after a person is dead will his body become rigid. It is the same with all myriad of things. When the flowers, grass 
and trees are alive, they are soft. Only after they are dead will they become rigid. From the above principle, it is true that those who are strong but stubborn are rushing along their path towards death. On the contrary, those who are humble and soft are trekking on the path of eternity. Therefore, those who rely on their military might and are fond of wars are usually defeated. This is like the big, strong tree that is usually the first one to be cut down. Those who are boastful of their strength are usually despised and looked down by others. Those who are humble and remain soft are the ones who receive respect and support from others.

A person living according to Dao is like an innocent and soft child (Chapter 55). Never underestimate anyone who appears to be meek and mild on the outside (Chapter 36). Only those who appear to be meek and mild can overcome those who appear to be strong and rigid. As Dao is most subtle, but everything originates from it (Chapter 6). A person with subtle Dao will avoid creating conflicts, like the light from a lamp being able to unite with everyone, mingling with the masses (Chapter 56). Female animals in this world are able to conquer stronger and restless male animals with tenderness and tranquility (Chapter 61). Although softness in management appears insignificant, it becomes the underlying principle in conquering hard force to encourage the real strength in employees.

Summarily, the goal that everyone should strive for is the tranquil original nature of non-action, and it is only through this original nature that everything is able to reside in its proper position, including the management (Chapter 45). Then, peace and harmony in the organization are achieved naturally. However, non-action management should also emphasize the details. The details decide the successful management (Chapter 52 and 63). As Chapter 63 presented that begin with successfully tackling trivial matters and then progress to accomplishing significant matters. To tackle difficult matters, one should start with easier ones. To accomplish significant matters, non-action management must start with trivial ones which offer a strong foundation for success.

\section{Constructing a Non-action Leadership Model}

Non-action management is based on the cultivation of non-action leadership. As a non-action cultivator, Laozi embodied his cultivation in his book Dao De Jing. Laozi is a great ancient Chinese philosopher, born approximately 2500 years ago. Laozi wrote his book by cultivating non-action characters: First, Laozi is peaceful. In Chapter 26, he presented that when one's heart is stable and at ease, one will not be distracted by external elegant and beautiful appearances. A person who behaves compulsively is forsaking his own foundation. Second, Laozi has low desire. In Chapter 29, he presented that even though human beings are supreme to all other beings, they cannot deviate from the principle of the world. They should not do anything inappropriate or do anything impractical. One must uphold a pure and innocent heart, maintain selflessness without desires, and restore one's purest and most genuine original nature (Chapter 19). Third, Laozi is gentle. In Chapter 78, he presented that water is most gentle of all things. Even though water is gentle, it always claims the final victory when it is attacked by anything strong. Those who are weak are able to conquer those who are strong. Finally, Laozi is tolerant. In Chapter 4, he presented that Dao is never competitive or in confrontation with all myriad of 
things. Instead, Dao is ever generous and tolerant in resolving conflicts. It exists wherever there is brightness. It exists wherever there is dust.

The cultivation of Dao can be either easy or difficult (Chapter 10). The minds of the ancient Dao cultivators were very profound and they are cautious, respectful, humble, tranquil and not arrogant or complacent (Chapter 15). Chapter 20 presented that people nowadays do not cultivate the virtues of their hearts. The fields of their hearts are all barren and deserted, which allow the weeds of anger and greed to grow unabated. Thus, Chapter 52 presented that one must constantly reflect upon oneself. Only one who is able to overcome himself can be considered the strongest person (Chapter 33). Cultivation is like repeatedly getting dressed in the morning (Chapter 59). Laozi in Chapter 67 presented three essentials regarding Dao cultivation to accumulate good virtues for non-action leadership (Figure 2): Firstly, one must maintain a merciful and loving heart. Secondly, be frugal, honest and simple. Lastly, never be egotistical, arrogant and boastful. Dao cultivation is urgent for intelligent leaders. As Chapter 41 presented that due to his great foundation and extensive knowledge, a sagely person has aspiring goals in life. As soon as he encounters the Dao, he realizes that Dao is what he strives to accomplish and he will embrace Dao immediately.

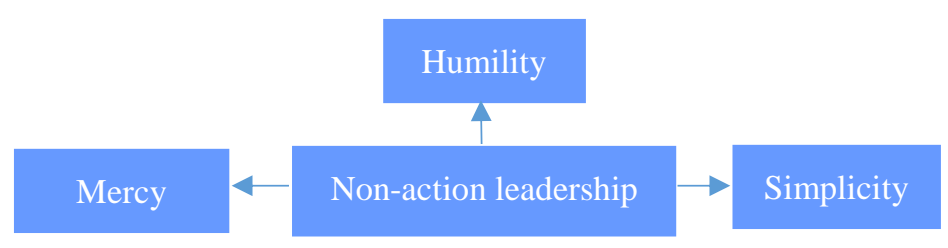

Figure 2. Non-action Leadership Construction Model

\section{Three essentials of Laozi - Mercy}

Mercy is the original nature bestowed by Dao. Dao nourishes all myriad of things indiscriminately (Chapter 79). A saint with deep virtues is someone who is broad-minded, impartial, unselfish and upholds the responsibility to save others (Chapter 16). Truly merciful people will not be hurt (Chapter 50). Like water brings benefits and nourishments to all myriad of things (Chapter 8). Water offers itself to everything based on its kind, loving nature. This is where water most resembles the function of Dao. Daoism says "the highest good is just like water" (Wilhelm and Baynes, 1967, p.274). Chapter 13 presented that if there is a person who values his body for the great mission of saving the world instead of indulging in luxury and wealth, then this kind of person can also be entrusted with governing the world. The virtue of mercy is the basic element of non-action leadership cultivation.

\section{Three essentials of Laozi - Simplicity}

Simplicity is both on material and spirituality. In the pursuit of external things, one will never find the true answer and instead will become increasingly deluded. No one should indulge in enjoyment which is as brief as the passage of a visitor (Chapter 35). The saints are aware of the 
pitfalls of materialistic desires, so they do not indulge in materialistic enjoyment (Chapter 12 and 64). Chapter 44 presented that a person will exhaust himself and lose out greatly if he pursues materialistic possession, fame and gains excessively. The more valuable possessions one owns, the greater the chance of inciting jealousy and hatred from others. Personal calamity will ensue. When everyone is greedy, the world will inevitably be engulfed with chaos and conflicts (Chapter 46). As worldly affairs are inexhaustible (Chapter 47), one who is able to reduce his desires will find himself spiritually rich (Chapter 22). Those who are greedy for materialistic possessions are most deluded.

\section{Three essentials of Laozi - Humility}

The behavior of being too arrogant and boastful is despicable (Chapter 24) Arrogance is a disease (Chapter 71). Chapter 9 indicated that a wealthy person who is not arrogant will receive sincere respect from others. Only one who remains humble of his accomplishments is in accordance with the natural spirit of Dao. A humble small stream which does not mind lying at the lowest point between mountains will naturally attract water from many sources (Chapter 28). As Chapter 66 presented that a saint always speaks humbly and regards himself as junior to others. One may seem to be deprived on the surface, but he actually gains in the end (Chapter 42). A person's mind must be fulfilled before he can manifest humility (Chapter 22). A truly virtuous person with a kind heart will not take credit even after he has performed many great deeds (Chapter 38). The true meaning of greatness is in the humility of Dao even though Dao upholds everything (Chapter 34) and benefit all myriad of things (Chapter 81).

\section{Applications and Implications}

\section{Cases related to non-action management}

In Chinese history, non-action management practiced in the Han and Tang dynasties achieved the first flourishing age and the highest level of economic and cultural development of Chinese feudal society. At the beginning of Han dynasty (about 2000 years ago), China was in chaos after years of warfare which led to social economic depression. Emperor Wen and Jing implemented non-action management policies as follows: 1) Let people work for their own living without taxation and maintain peace with neighboring countries; 2) Taking agriculture seriously, rewarding hard-work farmers and asking officials concerned about agriculture. Every spring, they personally ploughed and sowed, setting good examples to the people; 3) They practiced non-action leadership as well which was consistent with their management. Emperor Wen and Jing lived a very frugal life, saved state spending and prohibited strictly aristocrats and bureaucrats from extravagance; 4) They set good and virtues examples for people and implemented virtuous policies to guide and change people, not using weapons to suppress people. People lived a happy life. The society was peaceful and prosperous. In Chinese history, this period was called "Wen Jing Days" (Xiong and Yuan, 1999).

Another emperor who practiced non-action management is Li Shimin in Tang dynasty (about 1400 years ago), which pushed the Chinese traditional agriculture society into heyday. Emperor 
Li Shimin implemented non-action management policies as follows: 1) He attached importance to agriculture, practicing strict frugality, recuperating and building up strength of people; 2) He valued talents. He was open and humble to take others' advice and learned from history; 3) He respected life and customs of minorities; 4) Moreover, he was very careful about his own behavior as leader. Finally, achieving the ideal situation of a harmonious country. As the title of this emperor's reign is "Zhen Guan", this period is historically called "Government of Zhenguan" (Wing, 1986).

\section{A case related to non-action leadership}

Apart from the emperors Wen, Jing and Li who practiced non-action leadership, another nonaction leadership example can be found in the case of Inamori Kazuo. Kazuo founded two Fortune 500 companies. Kazuo's successful business ideas are embodied in the tenets of his company: Dao is the natural rule - behave Dao and respect Dao. Thus, his management ideas mainly came from Chinese Daoism. He mentions his non-action management thinking in his book Living Way (2012) that there is a mysterious strength in the universe that promotes the development of all living things through goodwill. If living beings grow with this good faith, they will find success. In his books Why People Live (2015), Behaving Way (2015), and Living Way (2012), Kazuo summarizes the cultivation rules of Daoistic non-action leadership: change one's attitude into one of appreciation, be grateful for competition because it brings about improvements and prosperity, chasten the nobler will, and create a more harmonious and diversified life. Kazuo successfully manage enterprises for 40 years through non-action leadership cultivation which includes the following aspects: approaching leadership work as a process for spiritual improvement, cultivating ethics, sharpening the heart through management work, donating his individual shares to employees, and converting to Buddhism after retirement. Kazuo regards the human being as the only creature with the ability and responsibility to think about the future of the earth and how to make life better. In promoting the responsibility of leaders, Kazuo has argued that more people and leaders should make the effort to recover the philosophy of Dao.

\section{Implications for practice of non-action management}

From above cases, there are two implications for the practice of non-action management. First, doing proper thing at proper time is essential characteristic of non-action management, that is to say, conducting wise management under the principle of Dao. On the one hand, how to avoid imprudent management? It depends on the cultivation of non-action leadership. On the other hand, non-action management in nature is to respect and love human being which also depends on the virtuous cultivation of non-action leadership. Thus, the other implication from these cases is that the cultivation of non-action leadership is the guarantee of non-action management, which is also the guarantee of the truly eternal success for both leaders and their business.

\section{Conclusion: The Value of Considering Dao Philosophy for Management}

Based on Dao De Jing, this article explained non-action management with two main models: 
non-action management construction model and non-action leadership model. Non-action management offers a new perspective for management research and practice from unique Dao philosophy. This research is based on Dao philosophy. What is the value for this research to consider Dao philosophy on management?

First, as Chapter 52 presented that Dao is the essence. Myriad of things are the manifestation of Dao. Nowadays, people recognize only tangible things instead of Dao. This situation is indeed entirely contrary to Dao. After a person has recognized Dao, he has to uphold the origin which creates everything in the world. Then, this person can be regarded as having returned to the embrace of Dao. He will not feel horrified or endangered even when he dies. As a result, we need to return to the origin of the universal law to rethink about the nature of human being and management.

Second, Chapter 40 presented that all myriad of things are trapped in the endless cycle of living and transformation. However, no matter how much transformation takes place, all myriad of things originate from the essence of Dao. Even though all myriad of things revolve over and over again, they will have to eventually return to the state of calmness and non-action. This non-action nature of all men provides the foundation for non-action management.

In summary, humanistic concerns in terms of recognizing and respecting human Dao nature of non-action are integrated with management. The original text of the Dao De Jing was used to give leaders specific rules for cultivating non-action management and leadership to help attain business success. This paper provides a basis for related research aimed at combining Eastern wisdom and philosophy with contemporary management knowledge. By considering the Dao De Jing and Dao philosophy as part of a valuable heritage Laozi gave to the world, future studies can further develop specific Dao approaches to guide management theory and practice.

\section{References}

Barkema, H. G., Chen, X. P., George, G., Luo, Y. and Tsui, A. S. (2015) "West meets east: new concepts and theories”, Academy of Management Journal, vol. 58, no. 2, pp. 460-479.

Javary, C. (1997) Understanding the I Ching, Boston, MA and London: Shambhala.

Jing, R. and Van de Ven, A. H. (2014) “A Yin-Yang Model of Organizational Change: The Case of Chengdu Bus Group”, Management and Organization Review, vol.10, no.1, pp. 29-54.

Kazuo, I. (2012) Living way, Beijing: Oriental Press.

Kazuo, I. (2015) Behaving way, Beijing: China Machine Press.

Kazuo, I. (2015) Why people live? Beijing: Oriental Press.

Lee, Y.-T., Han, A. G., Bryron, T. K. and Fan, H. X. (2008) "Daoist leadership: Theory and 
application", in Chen, C. C. and Lee, Y.-T. (eds.) Leadership \& management in China: Philosophies, theories and practices, New York: Cambridge University Press.

Ma, L. and Tsui, A. S. (2015) "Traditional Chinese philosophies and contemporary leadership", The Leadership Quarterly, vol. 26, no1., pp. 13-24.

Wilhelm, R. \& Baynes, C. F. trans. (1967) I Ching or book of changes ( $3^{\text {rd }}$ ed.), Princeton, NJ: Princeton University Press.

Wing, R. L. (1986) The Tao of power: a translation of the Tao Te Ching by Lao Tzu, Garden City, NY: Doubleday.

Xiong, L. H., and Yuan, Z. M. (1999) Laozi and modern management, Beijing: Xuelin.

Yao, D. \& Gan, S. (2013) Dao De Jing and Leadership, Beijing: Economic management press. 